\title{
Reproductive Functions in Male Patients with Epilepsy
}

\author{
Epilepsi Tanılı Erkek Hastalarda Üreme Fonksiyonları
}

\author{
(1) Can Çubuk, (1) Mehmet Taylan Peköz, (1) Hacer Bozdemir, (1) Kezban Aslan \\ Cukurova University Faculty of Medicine, Department of Neurology, Adana, Turkey
}

\begin{abstract}
Objective: Hormonal changes and abnormalities in reproductive function may occur in patients with epilepsy. This study aimed to investigate the abnormalities in the reproductive functions in male patients with epilepsy under antiepileptic treatment and its negative impact on their children.

Materials and Methods: A total of 104 participants were included in the study, wherein 52 were patients and 52 were healthy controls. Medical history and completed neurological examination were performed on all participants. Each participant filled out the International Index of Erectile Function (IIEF) and Beck depression scale. Serum hormones and biochemistry tests were also checked. Electroencephalography that was performed within the last 6 months and cerebral imaging anytime during the follow-up period were retrospectively evaluated. The Statistical Package for the Social Sciences 20.0 program was used for statistical evaluation.

Results: The mean age of the male patients with epilepsy was $29.1 \pm 5.5$ years. The prevalence of erectile dysfunction was $63.5 \%$ in male patients with epilepsy, and $40.4 \%$ of the patients developed erectile dysfunction after antiepileptic drug use. Patients on polytherapy were found to have a higher risk of depression. Furthermore, patients with intractable seizures were more depressed ( $\mathrm{p}=0.044)$. Beck scale and IIEF scores negatively affected each other (rs: -0.568 ). Patients with polytherapy have higher estrogen levels, whereas the luteinizing hormone levels were lower. Congenital malformation percentage is defined by $4.2 \%$ in children of male patients with epilepsy. Two of them have atrial septal defects and 1 with foramen ovale.

Conclusion: The possibility of congenital malformation and abnormalities in the children of male patients with epilepsy should not be overlooked. Patients and their relatives should be provided with the necessary support and information after careful risk assessment.
\end{abstract}

Keywords: Epilepsy, seizure, hormone, congenital malformation

$\ddot{O} \mathbf{z}$

Amaç: Epilepsi hastalarında hormonal değişiklikler ve üreme fonksiyonunda anormallikler meydana gelebilmektedir. Bu çalışmanın amacı, antiepileptik tedavi alan epilepsi tanılı erkek hastaların üreme işlevlerindeki anormalliklerin ve bu hastaların çocuklarında olumsuz etkilerinin araştırılmasıdır.

Gereç ve Yöntem: Çalışmaya 52 hasta ve 52 sağlıklı kontrol olmak üzere toplam 104 kişi dahil edilmiştir. Tüm katılımcıların tıbbi öyküleri alındı ve nörolojik muayeneleri yapıldı. Çalışmaya katılan her bir kişi Uluslararası Erektil İşlev Formu (IIEF) ve Beck depresyon ölçeğini doldurdu. Serum hormon ve biyokimyasal testleri yapıldı. Son altı ay içerisinde yapılan elektroensefalografi ve takibi süresince herhangi bir zamanda yapılan serebral görüntüleme bulguları retrospektif olarak de ğerlendirildi. Verilerin istatistiksel analizi için SPSS programı 20.0 sürüm kullanıldı.

Bulgular: Erkek epilepsi hastalarının yaş ortalaması 29,1 $\pm 5,5$ 'ti. Epilepsi tanılı erkek hastalarda erektil disfonksiyon prevalansı $\% 63,5$ olarak değerlendirildi.

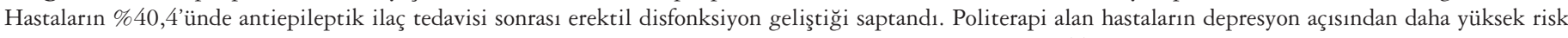
altında olduğu saptandı. Ayrıca, kontrolsüz nöbetleri olan hastaların daha depresif olduğu görüldü ( $\mathrm{p}=0,044)$. Beck depresyon ölçeğgi ve IIEF skorlarının ters orantılı olduğu belirlendi (rs: -0,568). Politerapi alan hastalarda östrojen seviyeleri daha yüksek, luteinize edici hormon seviyeleri daha düşüktü. Erkek epilepsi hastalarının çocuklarında konjenital malformasyon oranı \%4,2 olarak saptandı. Konjenital malformasyonlardan iki tanesi atriyal septal defekt olup bir tanesi de patent foramen ovale olarak değerlendirildi.

Sonuç: Epilepsi tanılı erkek hastaların çocuklarında konjenital malformasyon ve anormallik gelişme olasılığı göz ardı edilmemelidir. Dikkatli bir risk değerlendirmesi sonucunda hasta ve yakınlarına gerekli destek ve bilgi yol gösterici alacaktır.

Anahtar Kelimeler: Epilepsi, nöbet, hormon, konjenital malformasyon

Address for Correspondence/Yazışma Adresi: Can Çubuk MD, Cukurova University Faculty of Medicine, Department of Neurology, Adana, Turkey Phone: +90 5334983587 E-mail: cancubuk@hotmail.com ORCID: orcid.org/0000-0001-6311-0387

Received/Geliss Tarihi: 17.02.2021 Accepted/Kabul Tarihi: 13.04.2021

${ }^{\circ}$ Copyright 2021 by Turkish Neurological Society

Turkish Journal of Neurology published by Galenos Publishing House. 


\section{Introduction}

Reproductive endocrine disorders and impaired sexual function are prevalent in men who are diagnosed with epilepsy compared to the average population. Clinical studies reported that hyposexuality and decreased potency are observed in up to $71 \%$ of male patients with epilepsy. Epilepsy cites as the reason for this; however, antiepileptic medications also affect the endocrine function $(1,2)$. Besides, psychiatric disorders are the other reason for sexual dysfunction. Approximately $50 \%$ of patients with epilepsy have psychiatric disorders (3), the most common of which is interictal depression (4).

Maternal antiepileptic drug exposure during pregnancy may cause fetal congenital malformations. Many studies have examined the development of malformation in children born to female patients with epilepsy; however, studies that involved the development of malformation in children of male patients with epilepsy are insufficient. Therefore, this current study aimed to determine the congenital abnormalities/malformations in children of male patients with epilepsy and sexual dysfunction.

\section{Materials and Methods}

The study was conducted retrospectively and included 104 participants who were admitted to the neurology department from January 2017 until January 2018. The patients were classified into two groups: 52 men with epilepsy and 52 healthy controls. Consent forms were presented and explained orally to the participants before obtaining informed consent.

The participants' medical history was taken before the physical examination and was followed by a detailed neurological examination. The demographic, etiological, and clinical information of all participants were investigated. Seizure types were identified according to the 2017 International League Against Epilepsy classification. The electroencephalography examinations in the last 6 months and the cerebral imaging during the followup in all patients were retrospectively analyzed.

The International Index of Erectile Function (IIEF) was used to assess the participants. The IIEF is adapted and validated in Turkish (5). The IIEF form comprises five different assessments: IIEF-1 assesses erectile function, IIEF-2 assesses orgasmic function, IIEF-3 assesses sexual desire, IIEF-4 assesses sexual satisfaction, and IIEF-5 assesses general satisfaction; IIEF-1 values were used in the current study. IIEF-1 characterized the presence and level of erectile dysfunction (none, mild, mild-to-moderate, moderate, and serious). IIEF scores of 0-10, 11-16, 17-21, 22-25, and 2630 were considered serious, moderate, mild-to-moderate, mild, and no dysfunction, respectively. Moreover, the Beck depression scale was employed to characterize the presence and severity of depression (none, minimal, mild, moderate, and severe). Beck scores of 0-9, 10-16, 17-29, and 30-63 were considered minimal, mild, moderate, and severe depression, respectively. The normal aging process may lead to sexual dysfunction, thus the upper age limit was 40 years old in both groups. Serum fasting blood sugar, liver function tests, kidney function tests, sodium levels, thyroid function tests, B12 and testosterone levels in serum, luteinizing hormone $(\mathrm{LH})$, follicle-stimulating hormone $(\mathrm{FSH})$, prolactin (PRL), and estrogen levels were collected from each participant between 8 am and $10 \mathrm{am}$. A Joint Commission International
Accredited laboratory evaluated these findings. The normal ranges of hormonal parameters in serum were $2.41-8.27 \mathrm{ng} / \mathrm{ml}$ for total testosterone, 1.24-8.62 $\mathrm{mIU} / 1$ for $\mathrm{LH}, 1.27-19.26 \mathrm{mIU} / \mathrm{ml}$ for FSH, 2.1-17.7 $\mathrm{ng} / \mathrm{ml}$ for PRL, and 20-47 pg/ml for estrogen. In the epilepsy group, at least 1 week without seizures was required before blood collection. In all participants, the presence of spousal infertility or epilepsy, use of fertility treatment, medication history (both epileptic and other) of the participant and their spouse, and presence of abnormalities or malformations in the children of participants were investigated. The children of all participants were examined, and their medical histories were checked using the e-nabiz website (https://enabiz.gov.tr).

The Cukurova University Faculty of Medicine Ethics Council approved this study (document dated: 13.01.2017, numbered: 2017/66).

\section{Statistical Analysis}

All analyses were performed using International Business Machines Statistical Package for the Social Sciences Version 20.0 statistical software package. Categorical variables are expressed as numbers and percentages, and continuous variables are summarized as the mean and standard deviation and as median and minimummaximum as appropriate. The chi-square test was used to compare categorical variables between the groups. The Mann-Whitney U test was used for the comparison of continuous variables between the two groups. The Kruskal-Wallis test was used to compare more than two groups for non-normally-distributed data. The Spearman correlation coefficient was used to evaluate the correlations between measurements. The statistical level of significance for all tests was considered to be a $\mathrm{p}$ value of 0.05 .

\section{Results}

The distribution of the demographic, imaging, etiological, clinical, and electrophysiological examination results of the study participants are shown in Table 1. The study included 52 male patients with epilepsy and 52 healthy controls, between the ages of 20 and 40 years, who were followed up in our epilepsy polyclinic. Of the total included cases, $76.9 \%(n=40)$ were married, and $23.1 \%(n=12)$ were single. The mean age of patients with epilepsy was $29.1 \pm 5.5(20-40)$ years, and the mean age of the control group was $29.2 \pm 5.2(20-40)$ years. The follow-up period at the outpatient clinic, antiepileptic medications, and usage durations are shown in Table 2.

Of the participants who took antiepileptic medication, $40.4 \%$ $(\mathrm{n}=21)$ had impaired sexual function as defined by IIEF, whereas $59.6 \%(n=31)$ did not.

The participants' hormonal levels are shown in Table 3, and a comparison of hormone levels between the two groups demonstrated that the testosterone levels were significantly higher in the control group $(\mathrm{p}=0.012)[95 \%$ confidence interval (CI)$1.32--0.16)](\eta 2: 0.060)$.

The mean Beck depression scale and the IIEF scores were $15.8 \pm 12.8(0-45)$ and $18.2 \pm 10(1-30)$, respectively, among the patients with epilepsy, and $2.8 \pm 3.4(0-15)$ and $29.5 \pm 1.3$ (26$30)$, respectively, in the control group. The mean Beck depression scale score was lower in the control group (95\% CI 9.19-16.57) ( $12: 0.323)$, whereas the mean IIEF score was lower in the patient group $(95 \% \mathrm{CI}-14.13--8.51)(\eta 2=0.390)(\mathrm{p}<0.05)$. 


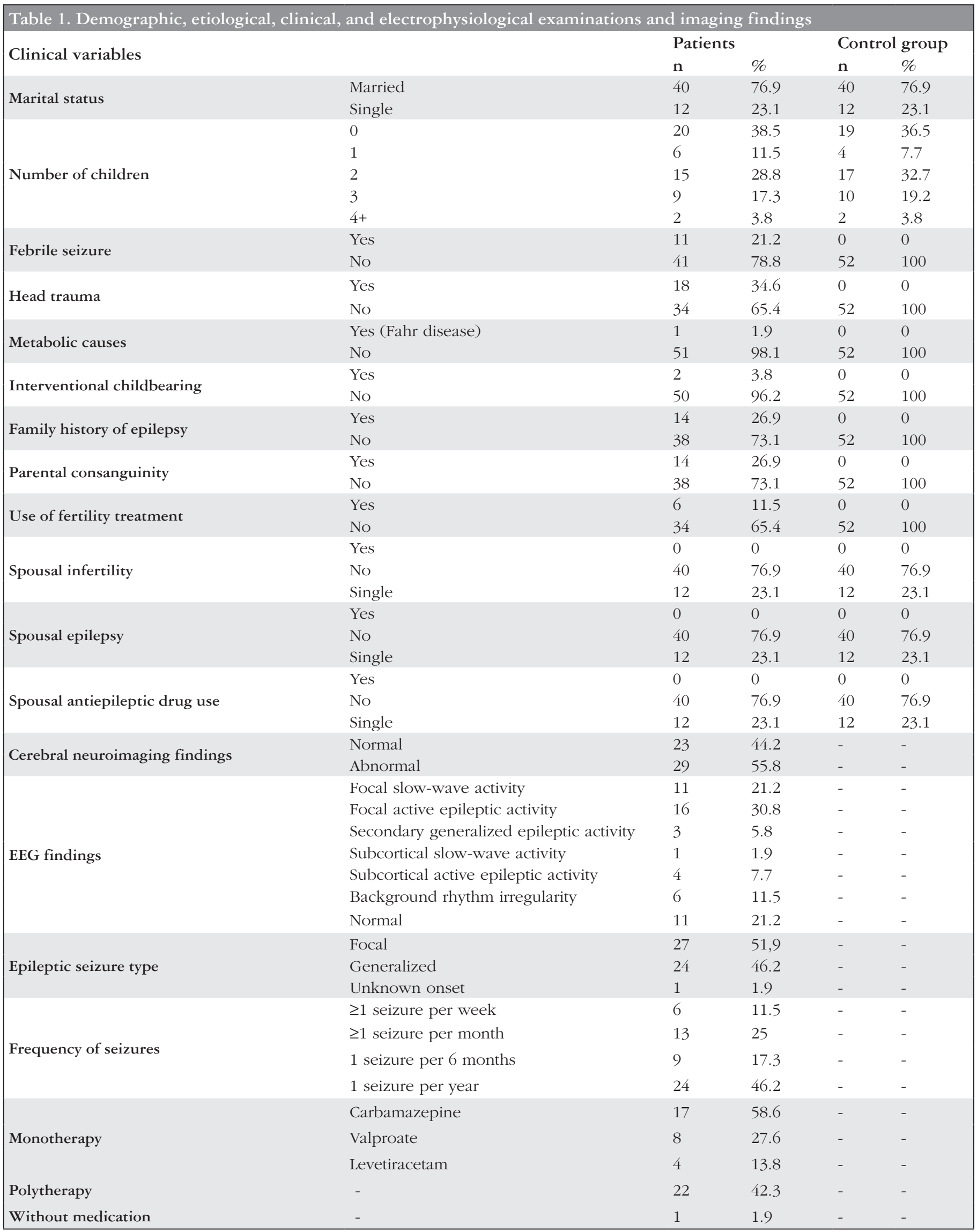


Table 2. The antiepileptic medications used by patients with epilepsy, durations of medication usage, and followup period at the outpatient clinic

\begin{tabular}{|c|c|c|}
\hline Patient (\#) & $\begin{array}{l}\text { Antiepileptic medications and } \\
\text { duration (year) }\end{array}$ & $\begin{array}{l}\text { Follow-up } \\
\text { period (year) }\end{array}$ \\
\hline \#1 & CBZ (10) & 8 \\
\hline \#2 & CBZ (20) & 20 \\
\hline \#3 & CBZ (13) & 13 \\
\hline$\# 4$ & CBZ (15) & 15 \\
\hline \#5 & CBZ (4) & 4 \\
\hline \#6 & CBZ (11) & 10 \\
\hline \#7 & CBZ (14.5) & 12 \\
\hline$\# 8$ & CBZ (8) & 6 \\
\hline \#9 & CBZ (5.5) & 6 \\
\hline$\# 10$ & CBZ (17.5) & 16 \\
\hline$\# 11$ & CBZ (9) & 10 \\
\hline \#12 & CBZ (5) & 6.5 \\
\hline$\# 13$ & CBZ (18) & 12 \\
\hline \#14 & CBZ (26) & 22 \\
\hline \#15 & CBZ (4.5) & 6 \\
\hline \#16 & CBZ (13.5) & 8 \\
\hline$\# 17$ & CBZ (12) & 13 \\
\hline \#18 & VPA (13) & 11 \\
\hline \#19 & VPA (5) & 5 \\
\hline$\# 20$ & VPA (9) & 9 \\
\hline$\# 21$ & VPA (14) & 14 \\
\hline$\# 22$ & VPA (9.5) & 5 \\
\hline$\# 23$ & VPA (17) & 17 \\
\hline$\# 24$ & VPA (24) & 14 \\
\hline$\# 25$ & VPA (6) & 6 \\
\hline$\# 26$ & LEV (3) & 3 \\
\hline$\# 27$ & LEV (5) & 5 \\
\hline \#28 & $\operatorname{LEV}(4.5)$ & 4,5 \\
\hline$\# 29$ & LEV (2) & 2 \\
\hline$\# 30$ & $\begin{array}{l}\text { CBZ (12)+VPA (16) +LEV (4) + } \\
\text { PRM (14) }\end{array}$ & 10 \\
\hline \#31 & $\mathrm{VPA}(4)+\mathrm{OXC}(5)$ & 5 \\
\hline \#32 & VPA (12) + LCM (2) & 12 \\
\hline$\# 33$ & $\begin{array}{l}\text { CBZ (14) +VPA (8) +LEV (5) + } \\
\text { TPM (3) }\end{array}$ & 14 \\
\hline$\# 34$ & VPA (8) + LEV (5) & 10 \\
\hline$\# 35$ & $\operatorname{VPA}(12)+\operatorname{LEV}(7)$ & 12 \\
\hline \#36 & CBZ (6) +LEV (3) + TPM (4) & 5 \\
\hline$\# 37$ & CBZ (12) + LTG (6) & 8 \\
\hline \#38 & CBZ (10.5) + VPA (8) & 11 \\
\hline$\# 39$ & CBZ (14) + VPA (6) & 14 \\
\hline
\end{tabular}

Table 2. contiuned

\begin{tabular}{|lll|} 
Patient (\#) & $\begin{array}{l}\text { Antiepileptic medications and } \\
\text { duration (year) }\end{array}$ & $\begin{array}{l}\text { Follow-up } \\
\text { period (year) }\end{array}$ \\
\hline \#40 & CBZ (3) + VPA (3) + LEV (2) & 3 \\
$\# 41$ & CBZ (12) + VPA (8) + LEV (3) & 10.5 \\
$\# 42$ & CBZ (8.5)+ PB (14) & 6 \\
$\# 43$ & VPA (12) + LEV (5.5) + OXC (8) & 12 \\
$\# 44$ & CBZ (14) + LEV (1) & 10 \\
\#45 & CBZ (4) + LEV (2) & 4 \\
\#46 & CBZ (5) + LEV (0.5) & 5 \\
\#47 & CBZ (16) + LEV (4) + PRM (8.5) & 12 \\
+ TPM (10) & 10 \\
\#48 & CBZ (10) + VPA (8.5) + LEV & 11 \\
\#49 & CB.5) + LTG (4) & 8 \\
\#50 & CBZ (4) + PHT (8) & 12 \\
\#51 & CBZ (11) + VPA (9.5) + TPM (3) & 12 \\
\#52 & Without medication & 4 \\
$\begin{array}{l}\text { CBZ: Carbamazepine, VPA: Valproate, LEV: Levetiracetam, PRM: Primidone, } \\
\text { OXC: Oxcarbazepine, LCM: Lacosamide, TPM: Topiramate, LTG: Lamotrigine, } \\
\text { PB: Phenobarbital, ZNS: Zonisamide, PHT: Phenytoin }\end{array}$ \\
\hline
\end{tabular}

Based on the IIEF, erectile dysfunction in patients with epilepsy was severe in $26.9 \%(n=14)$ of cases, moderate in $21.2 \%(n=11)$, mild-to-moderate in $5.8 \%(\mathrm{n}=3)$, and mild in $9.6 \%(\mathrm{n}=5)$. Additionally, $19.2 \%(\mathrm{n}=10)$ of patients with epilepsy had severe depression based on the Beck depression scale. The percentage of patients with no depression, minimal depression, mild depression, and moderate depression were $7.7 \%(n=4), 32.7 \%(n=17), 15.4 \%$ $(\mathrm{n}=8)$, and $25 \%(\mathrm{n}=13)$, respectively.

The coefficient $r_{s}$ based on the Spearman correlation analysis of the Beck and the IIEF scores was -0.599 . The scores were found to negatively affect each other, indicating that, as the Beck scores increased, the IIEF scores decreased. Depression increased as the Beck score increased. The erectile dysfunction level increased as the IIEF score decreased, indicating that depression and erectile dysfunction are statistically inversely proportional and clinically directly proportional. The comparison of Beck depression scores according to seizure prognoses revealed a mean Beck depression score of $13.2 \pm 12.5(0-45)$ among patients whose seizures were under control, and 20.2 $\pm 12.6(0-41)$ among the cases whose seizures were not, and presenting a statistically significant difference $(\mathrm{p}=0.044)$.

The hormonal values comparison according to the use of antiepileptic medications (polytherapy/monotherapy) revealed that serum estrogen levels were significantly higher in patients under polytherapy $(\mathrm{p}=0.013)$. This evaluation was based on 51 patients, excluding 1 patient who did not take any antiepileptic medications.

Children of patients with epilepsy were found to have congenital malformations and abnormalities (3 epilepsy, 1 goiter, 1 undervirilized male, 1 congenital myotonia, 2 atrial septal defects, and 1 patent foramen ovale). Table 4 shows the abnormalities, congenital malformations, and patients' antiepileptic medications and doses. All malformations were cardiac. The presence of 
Table 3. Hormone concentrations of the patients and control group

\begin{tabular}{lllll} 
Hormones & Patient & Control group & p values \\
Testosterone & $3.7 \pm 1.6(1.7-9.7) \mathrm{ng} / \mathrm{ml}$ & $4.5 \pm 1.4(1.6-7.8) \mathrm{ng} / \mathrm{ml}$ & 0.012 \\
Luteinizing hormone & $6.8 \pm 7.5(1.7-56.9) \mathrm{mIU} / 1$ & $7.0 \pm 1.5(2.3-8.9) \mathrm{mIU} / 1$ & 0.905 \\
Follicle-stimulating hormone & $7.8 \pm 6.6(1.4-45.7) \mathrm{mIU} / \mathrm{ml}$ & $6.4 \pm 3.7(1.5-23.4) \mathrm{mIU} / \mathrm{ml}$ & 0.178 \\
Prolactin & $7.2 \pm 2.5(2.4-13.4) \mathrm{ng} / \mathrm{ml}$ & $6.9 \pm 3.3(2.6-19.2) \mathrm{ng} / \mathrm{ml}$ & 0.563 \\
Estrogen & $26.0 \pm 17.3(1-71) \mathrm{pg} / \mathrm{ml}$ & $25.5 \pm 4.9(18-44) \mathrm{pg} / \mathrm{ml}$ & 0.843 \\
\hline
\end{tabular}

Table 4. Abnormalities and malformations in the children of patients with epilepsy and its relationship with antiepileptic medication

\begin{tabular}{llllc} 
Abnormalities & & \multicolumn{2}{c}{ Antiepileptic medications (mg/day)-(duration, year) } \\
Epilepsy 1 & Carbamazepine & Valproate & Levetiracetam & Oxcarbazepine \\
Epilepsy 2 & - & $2000(4)$ & - & $1800(5)$ \\
Epilepsy 3 & $1200(5)$ & - & $1000(0.5)$ & - \\
Goitre & - & $1000(9)$ & - & - \\
Undervirilized male disorder & - & $1500(3)$ & $3000(2)$ & - \\
Congenital myotonia & $400(15)$ & $1500(8)$ & $2000(5)$ & - \\
Atrial septal defect 1 & - & - & - & - \\
Atrial septal defect 2 & - & $1500(6)$ & - & - \\
Patent foramen ovale & - & $1500(12)$ & $3000(7)$ & - \\
\hline
\end{tabular}

abnormalities in children comparison according to the patients' hormonal levels revealed that one of the patients had a child with an abnormally high estrogen value, who was an undervirilized male disorder.

\section{Discussion}

A total of $63.5 \%(n=33)$ of the 52 male patients with epilepsy had erectile dysfunction ranging from mild to severe. The prevalence of sexual dysfunction in men with epilepsy has been reported as 31-67\% (6). Reis et al. (7) have determined the rate of erectile dysfunction as $65.1 \%$ in Brazilian men with epilepsy using the IIEF-5 values. The current study detected a prevalence rate of erectile dysfunction that was consistent with that previously reported in the literature.

In the present study, men with epilepsy were found to have lower testosterone levels and a higher percentage of erectile dysfunction based on the comparison between the patient and control groups. These findings were consistent with those of the previous reports $(8,9)$. Our patients with polytherapy have significantly higher estrogen levels compared to those with monotherapy. Estrogen is known to decrease libido and potency. Estrogen inhibits LH secretion and results in hypogonadotropic hypogonadism (10). Vieira et al. (11) revealed that the mean IIEF score was higher in the group with monotherapy than in the group with polytherapy. In our study, IIEF scores did not vary between monotherapy and polytherapy groups. The conflicting result in our study may be due to an insufficient number of patients. In a subgroup analysis of patients undergoing monotherapy with carbamazepine, valproate, and levetiracetam, the IIEF and Beck scores were compared and no statistically significant difference was found ( $\mathrm{p}=0.899, \mathrm{p}=0.375)$.

Literature found a relationship between uncontrolled seizures and major depression (12). In this study, patients whose seizures were not under control had a higher Beck depression score, consistent with previous findings. In a review, factors associated with erectile dysfunction in men with epilepsy were recorded as; higher seizure frequency, anxiety, and depression (13). When the scores on the Beck scale and IIEF were correlated, it was found that they negatively affected each other $\left(r_{s}:-0.599\right)$ (Figure 1). In a study by Hassan et al. (14) a negative correlation was identified between the IIEF and Beck scores, which was similar to our study results (r: 0.54).

Numerous studies are reported on malformations in children of women with epilepsy $(15,16,17,18)$. Yang et al. (19) determined that the risk of circulatory system abnormalities increased by 1.39 and the risk of genital organ abnormalities increased by 1.09 times in children whose fathers use antiepileptic drugs. In our study, the percentage of congenital malformations in the children of patients with epilepsy was found as $4.2 \%(\mathrm{n}=3)$, all of which were cardiac malformations ( 2 atrial septal defects and 1 patent foramen ovale). A total of 9 children of patients with epilepsy had abnormalities, including cardiac malformations that were previously mentioned. The other 6 children had several abnormalities (epilepsy in 3, undervirilized male disorder in 1, goiter in 1, and congenital myotonia in 1). Undervirilized male disorder is incomplete virilization of $\mathrm{XY}$ males and has two main mechanisms; defective testicular development and defective male differentiation of 


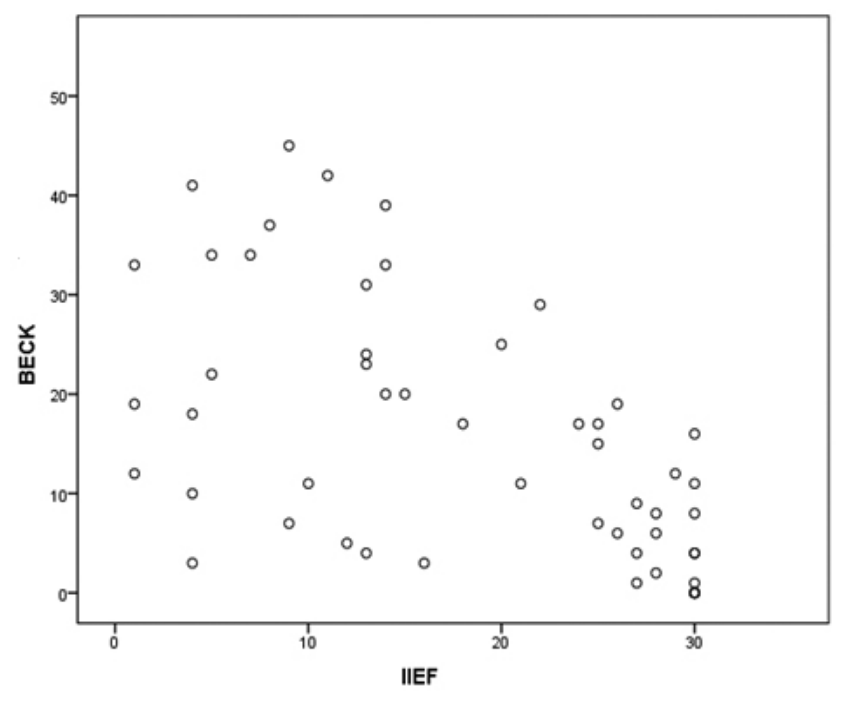

Figure 1. Scatter plot for correlation between IIEF and Beck scores IIEF: International Index of Erectile Function

external and/or internal genitalia (20). Moreover, the parents of the children with abnormalities showed no consanguinity. No abnormalities and/or malformations were found in the children of the healthy group.

Consanguineous marriage $(26.9 \%, \mathrm{n}=14)$ was observed only in the epileptic group that may suggest the autosomal recessive inheritance of epilepsy, and three children of these epileptic patients draw attention by having epilepsy, which suggests a higher incidence of given genetics from their fathers. Epidemiological studies on congenital malformation/abnormalities in Turkey are insufficient. In the literature, the atrial septal defect prevalence is 4.6 per 1000 live birth in Anatolia (21). In our study, the atrial septal defect rate of children of male patients with epilepsy is observed as $2.7 \%$. Cetin et al. (22) have determined the prevalence of goiter in Isparta city, which is in the Mediterranean region same as Adana as $26 \%$. In our study, goiter prevalence among children of male patients with epilepsy was $1.4 \%$. Our study showed that the prevalence of epilepsy was $4.1 \%$ among the children of male patients with epilepsy. Karabiber et al. (23) reported the prevalence of epilepsy in the city of Malatya as $0.8 \%$. No previous studies were reported about the prevalence of undervirilized male disorder or congenital myotonia in our region and/or country. Another condition that should not be ignored is the antiepileptic medications taken by patients who have children with malformations. In the current study, valproate and levetiracetam were taken by fathers whose children had a cardiac malformation (Table 4). Following a review of the literature, levetiracetam and valproate were found to affect sperm morphology, particularly, causing deformities in the sperm heads (24). Furthermore, Sveberg Røste et al. (25) demonstrated that valproate had a toxic effect on seminiferous tubules in Wistar rats. A review on the impact of valproate on sexual and reproductive health in men with epilepsy revealed lower free testosterone, sperm count and motility, testicular volume, IIEF scores, raised serum estradiol, and androstenedione, and higher rates of abnormalities in sperm (26).

\section{Conclusion}

In conclusion, we found that psychiatric changes may occur in addition to impaired sexual and reproductive functions in male patients with epilepsy, primarily due to epilepsy or antiepileptic medications used by the patient. Furthermore, we conclude that male patients with epilepsy may be more likely to have children with abnormalities, thus should be thoroughly investigated in the future.

\section{Ethics}

Ethics Committee Approval: The Cukurova University Faculty of Medicine Ethics Council approved this study (document dated: 13.01.2017, numbered: 2017/66).

Informed Consent: The purpose of the study was explained to the participants before their informed written consent was obtained.

Peer-review: Externally peer-reviewed.

\section{Authorship Contributions}

Surgical and Medical Practices: C.Ç., M.T.P., H.B., K.A., Concept: C.Ç., H.B., K.A., Design: C.Ç., M.T.P., H.B., Data Collection or Processing: C.Ç., M.T.P., H.B., K.A., Analysis or Interpretation: C.Ç., M.T.P., H.B., Literature Search: C.Ç., M.T.P., H.B., K.A., Writing: C.Ç., M.T.P., H.B., K.A.

Conflict of Interest: No conflict of interest was declared by the authors.

Financial Disclosure: The authors declared that this study received no financial support.

\section{References}

1. Isojärvi JI, Löfgren E, Juntunen KS, et al. Effect of epilepsy and antiepileptic drugs on male reproductive health. Neurology 2004;62:247-253.

2. Fawley JA, Pouliot WA, Dudek FE. Epilepsy and reproductive disorders: the role of the gonadotropin-releasing hormone network. Epilepsy Behav 2006;8:477-482.

3. Marsh L, Rao V. Psychiatric complications in patients with epilepsy: a review. Epilepsy Res 2002;49:11-33.

4. Marcangelo MJ, Ovsiew F. Psychiatric aspects of epilepsy. Psychiatr Clin North Am 2007;30:781-802.

5. Akkus E, Kadioglu A, Esen A, et al. Prevalence and correlates of erectile dysfunction in Turkey: a population-based study. Eur Urol 2002;41:298304.

6. Sivaraaman K, Mintzer S. Hormonal consequences of epilepsy and its treatment in men. Curr Opin Endocrinol Diabetes Obes 2011;18:204-209.

7. Reis RM, de Angelo AG, Sakamoto AC, Ferriani RA, Lara LA. Altered sexual and reproductive functions in epileptic men taking carbamazepine. J Sex Med 2013;10:493-499.

8. Herzog AG, Drislane FW, Schomer DL, et al. Differential effects of antiepileptic drugs on sexual function and hormones in men with epilepsy. Neurology 2005;65:1016-1020.

9. Ocek L, Tarhan H, Uludağ FI, et al. Evaluation of sex hormones and sperm parameters in male epileptic patients. Acta Neurol Scand 2018;137:409416.

10. Herzog AG. Disorders of reproduction in patients with epilepsy: primary neurological mechanisms. Seizure 2008;17:101-110.

11. Vieira FC, Ronsoni MF, Hohl A, et al. How predictable is the erectile function of patients with epilepsy? Epilepsy Behav 2015;47:61-65.

12. Dias R, Bateman LM, Farias ST, et al. Depression in epilepsy is associated with lack of seizure control. Epilepsy Behav 2010;19:445-447.

13. Rathore C, Henning OJ, Luef G, Radhakrishnan K. Sexual dysfunction in people with epilepsy. Epilepsy Behav 2019;100(Pt A):106495. 
14. Hassan K, Elimeleh Y, Shehadeh M, Fadi H, Rubinchik I. The relationship between hydration status, male sexual dysfunction and depression in hemodialysis patients. Ther Clin Risk Manag 2018;14:523-529.

15. Deck GM, Nadkarni N, Montouris GD, Lovett A. Congenital malformations in infants exposed to antiepileptic medications in utero at Boston Medical Center from 2003 to 2010. Epilepsy Behav 2015;51:166-169.

16. Thomas SV, Jose M, Divakaran S, Sankara Sarma P. Malformation risk of antiepileptic drug exposure during pregnancy in women with epilepsy: Results from a pregnancy registry in South India. Epilepsia 2017;58:274281.

17. Tomson T, Xue H, Battino D. Major congenital malformations in children of women with epilepsy. Seizure 2015;28:46-50.

18. Tomson T, Battino D, Bonizzoni E, et al. Antiepileptic drugs and intrauterine death: A prospective observational study from EURAP. Neurology 2015;85:580-588.

19. Yang F, Yuan W, Liang H, et al. Preconceptional paternal antiepileptic drugs use and risk of congenital anomalies in offspring: a nationwide cohort study. Eur J Epidemiol 2019;34:651-660.

20. Nicolino M, Bendelac N, Jay N, Forest MG, David M. Clinical and biological assessments of the undervirilized male. BJU Int 2004;93 Suppl 3:20-5.
21. Başpinar O, Karaaslan S, Oran B, et al. Prevalence and distribution of children with congenital heart diseases in the central Anatolian region, Turkey. Turk J Pediatr 2006;48:237-243.

22. Cetin H, Kisioglu AN, Gursoy A, Bilaloglu E, Ayata A. Iodine deficiency and goiter prevalence in Turkey after mandatory iodization. J Endocrinol Invest 2006;29:714-718.

23. Karabiber H, Yakinci C, Durmaz Y, Kutlu O, Soylu H. Prevalence of epilepsy in 3637 children of primary school age in the province of Malatya, Turkey. J Trop Pediatr 2001;47:188-189.

24. Xiaotian X, Hengzhong Z, Yao X, et al. Effects of antiepileptic drugs on reproductive endocrine function, sexual function and sperm parameters in Chinese Han men with epilepsy. J Clin Neurosci 2013;20:1492-1497.

25. Sveberg Røste L, Taubøll E, Berner A, et al. Morphological changes in the testis after long-term valproate treatment in male Wistar rats. Seizure 2001;10:559-565.

26. Watkins LV, Angus-Leppan H. Valproate, sexual health, and men: A narrative review. Epilepsy Behav 2020;103:106835. 